\title{
PENGARUH VARIASI PUTARAN SPINDEL TERHADAP GAYA POTONG PADA PROSES PEMESINAN
}

\author{
Arya Rudi Nasution \\ Rahmatullah, \\ Universitas Muhammadiyah Sumatera Utara \\ Jagodang Harahap* \\ Akademi Komunitas Negeri Aceh Barat
}

\begin{abstract}
This study aims to see the cutting force that occurs during the lathe machining process using two different types of aluminum specimens. The research data collection method uses sensor aids; there are three sensors: a load cell sensor for cutting force, a photoelectric counter module for rotation (rpm), and a thermocouple for feeding temperature. The results showed that each specimen tested had a different value in each test, such as testing on Pure Aluminum (Al 1100) specimens with a depth of cut of $0.3 \mathrm{~mm}$ and variations in rotation. It can be seen that the DCMT tool blade is greater than the cutting force DCGT chisel. The cutting force produced on the DCMT tool blade is $9.91 \mathrm{~N}$ with a rotation of $90 \mathrm{rpm}$, and at $190 \mathrm{rpm}$ the DCMT tool gets a force of $6.83 \mathrm{~N}$. Whereas in the $\mathrm{Al}$ 2024 specimen using the DCMT chisel, the highest cutting force was at $90 \mathrm{rpm}$ rotation of $8.34 \mathrm{~N}$, and there was a decrease at $190 \mathrm{rpm}$ rotation of 4.56N. For DCGT chisels using Al 1100 specimens, the highest cutting force results at $90 \mathrm{rpm}$ rotation of $4.22 \mathrm{~N}$ and a decrease in cutting force at $190 \mathrm{rpm}$ rotation of $2.9 \mathrm{~N}$, and for the highest cutting force in $\mathrm{Al} 2024$ specimens at $90 \mathrm{rpm}$ rotation of $3.84 \mathrm{~N}$, experienced a decrease in cutting force at $190 \mathrm{rpm}$ rotation of $3.2 \mathrm{~N}$. It can be concluded that the decrease in cutting force is influenced by the amount of rpm used because the vibration that occurs is also large.
\end{abstract}

Keywords:

Spindle speed, Cutting force, Tool insert.

Penelitian ini bertujuan untuk melihat gaya potong yang terjadi pada saat proses pemesinan bubut dengan menggunakan 2 jenis spesimen aluminium yang berbeda. Metode pengambilan data penelitian menggunakan alat bantu sensor, ada tiga sensor yaitu sensor load cell untuk gaya potong, photoelectric counter module untuk putaran (rpm) dan thermocouple untuk temperatur pemakanan. Hasil penelitian menunjukan bahwa setiap spesimen yang di uji memiliki nilai yang berbeda disetiap pengujian, seperti pengujian pada spesimen Alumunium Murni (Al 1100) dengan kedalaman pemakanan (depth of cut) sebesar $0,3 \mathrm{~mm}$ dan variasi putaran, dapat diketahui pada mata pahat DCMT lebih besar gaya potong yang terjadi dibandingkan dengan pahat DCGT. Gaya potong yang dihasilkan pada mata pahat DCMT sebesar 9,91N dengan putaran $90 \mathrm{rpm}$ dan pada putaran $190 \mathrm{rpm}$ pahat DCMT mendapat gaya sebesar 6,83N. Sedangkan pada spesimen Al 2024 menggunakan pahat DCMT gaya potong yang tertinggi pada putaran $90 \mathrm{rpm}$ sebesar 8,34N dan terjadi penurunan pada putaran $190 \mathrm{rpm}$ sebesar 4,56N. Untuk pahat DCGT menggunakan spseimen Al 1100 hasil gaya potong yang tertinggi pada putaran $90 \mathrm{rpm}$ sebesar 4,22N dan terjadi penurunan gaya potong pada putaran $190 \mathrm{rpm}$ sebesar $2,9 \mathrm{~N}$, dan untuk gaya potong yang tertinggi pada spesimen $\mathrm{Al}$ 2024 pada putaran $90 \mathrm{rpm}$ sebesar 3,84N, mengalami penurunan gaya potong pada putaran $190 \mathrm{rpm}$ sebesar 3,2N. Dapat disimpulkan bahwasanya penurunan gaya potong dipengaruhi oleh besarnya rpm yang digunakan, karena getaran yang terjadi juga besar.

Kata Kunci:

Spindle speed, Gaya potong, Tool insert.

DOI:10.38038/vocatech.v2i2.56

Received: 13 February 2021 ; Accepted: 13 April 2021 ; Published: 20 April 2021

${ }^{*}$ Corresponding author:

Jagodang Harahap, Program Studi Teknologi Pengelasan Logam, Akademi Komunitas Negeri Aceh Barat, Komplek STTU Alue Peunyareng Meureubo, Meulaboh 23681.

Email:jagodang@aknacehbarat.ac.id

Citation in APA Style: Nasution, A.R., Rahmatullah., \& Harahap, J. (2021). Pengaruh Variasi Putaran Spindel Terhadap Gaya Potong Pada Proses Pemesinan, VOCATECH: Vocational Education and Technology Journal Vol. 2, 2 (2021), 95-103. 


\section{PENDAHULUAN}

Pemesinan adalah proses manufaktur industri yang banyak digunakan di mana cairan pemotongan sering memainkan peran penting dalam hal kualitas dan efisiensi pemesinan karena fungsi pelepasan pelumas, pendinginan, dan chipnya (Cetin et al., 2011). Pemesinan kering atau hampir kering sering dianggap sebagai strategi yang efektif untuk mengurangi dampak lingkungan dari proses pemotongan (Jiang et al., 2015; Nasution, 2019). Dalam industri permesinan, cutting tool berbahan dasar karbida telah menjadi tool yang paling banyak digunakan sejak diperkenalkan di Jerman pada 1920-an untuk memenuhi persyaratan ketahanan aus yang tinggi di industri cetakan (Iqbal et al., 2015).

Industri permesinan merupakan bagian dari industri manufaktur yang pengerjaannya menggunakan alat potong (cutting tool) untuk memotong benda kerja. Pada saat proses pemotongan pahat akan menghasilkan gaya pemotongan yang dipengaruhi oleh parameter putaran spindel, pemakanan dan kedalaman potong. Penelitian ini bertujuan untuk mengetahui secara akurat pengukuran gaya radial dan mengetahui parameter yang berpengaruh terhadap gaya pemotongan (Muhklisin et al., 2020).

Salah satu proses pemotongan logam yang paling banyak digunakan dalam industri manufaktur adalah proses pembubutan (M. Rizal. 2018). Proses pembubutan merupakan salah satu proses yang sering digunakan untuk konstruksi elemen mesin di industri manufaktur yaitu dirgantara, otomotif, perkapalan. Proses pemotongan logam merupakan suatu proses yang digunakan untuk mengubah bentuk suatu produk dari logam (komponen mesin perkakas) dengan cara memotong, selain itu proses pemotongan logam merupakan kegiatan terbesar yang dilakukan pada industri manufaktur, proses ini mampu menghasilkan komponen-komponen yang memiliki bentuk yang kompleks dengan akurasi geometri dan dimensi yang tinggi (Husni et al., $\underline{2019)}$.

Pada proses pembubutan material benda kerja diputar dan cutting tool bergerak ke kiri menghilangkan lapisan permukaan (chip) material benda kerja, menghasilkan tiga komponen cutting force yaitu gaya potong utama $\mathrm{F}_{\mathrm{c}}$ yang bekerja pada arah kecepatan potong. Gaya umpan $\mathrm{F}_{\mathrm{f}}$, yang bekerja pada arah laju umpan dan gaya dorong $\mathrm{F}_{\mathrm{t}}$, yang bekerja pada arah yang normal ke pemotongan kecepatan (Günay et al., 2008).
Alternatif untuk pengukuran gaya potong adalah dengan menerapkan konsep deformasi elastis material. Salah satunya pengukuran dengan alat bantu instrument dynamometer. Prinsip dari dinamometer ini adalah pendeteksian tekanan oleh bahan piezoelektrik yang digunakan sebagai elemen utama dalam konstruksi dinamometer, yang kemudian diubah menjadi muatan listrik proporsional (Scheffer \& Heyns, 2004).

Gaya potong (cutting force) yang dihasilkan pada proses pembubutan ada tiga macam, yaitu gaya tangensial, gaya aksial, dan gaya radial. Gaya tangensial, yaitu gaya yang dihasilkan pada arah kecepatan potong. Gaya aksial, yaitu gaya yang terjadi pada arah gerak makan. Sedangkan gaya radial, yaitu gaya yang arahnya menuju bidang normal pada kecepatan potong (Kosaraju. 2011).

Besarnya gaya potong merupakan informasi yang sangat diperlukan dalam mesin perkakas, besarnya gaya potong dipengaruhi oleh beberapa faktor salah satunya adalah putaran spindel dan beberapa faktor lain seperti tebal gram, kedalaman potong dan lainya. Gaya pemotongan merupakan informasi paling signifikan dalam proses pemesinan untuk mengetahui sebuah parameter pemotongan dan pengoptimalan geometri pahat, desain peralatan mesin, pengujian kemampuan mesin material baru dan sistem pemantauan kondisi pahat (Rizal et al., 2015).

Tujuan penelitian ini adalah melihat pengaruh dari variasi putaran spindel terhadap gaya potong yang dihasilkan pada proses pembubutan.

\section{STUDI PUSTAKA}

Proses pembubutan adalah sebuah proses pemesinan yang mengunakan satu mata potong untuk membuang material dari permukaan benda kerja yang berputar. Pahatnya bergerak pada arah linier sejajar dengan sumbu putar benda kerja. Pahat dipasangkan pada dudukan pahat (tool post) dan mengatur kedalaman potong sebelum melakukan pengerjaan material (Bharilya et al., 2015). Pengoperasian dasar pada mesin bubut adalah melibatkan benda kerja yang berputar dan cutting tool-nya bergerak linier atau benda kerja berputar pada angka putaran tertentu kemudian alat potong bergerak maju dengan kecepatan tertentu sehingga terjadi pemotongan yang menghasilkan tatal/geram (Susila. 2013). 


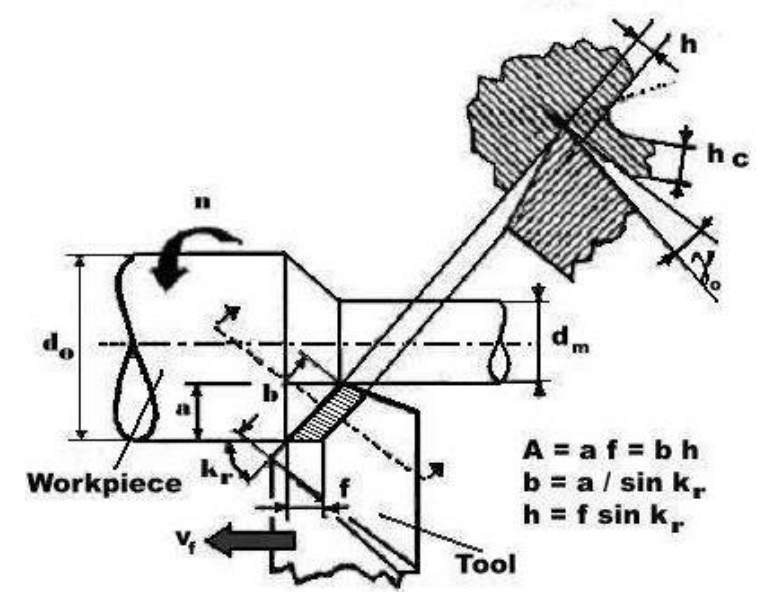

Gambar 1. Proses bubut (Rochim. 2013)

\section{A. Geometri pahat bubut}

Geometri atau bentuk pahat bubut terutama tergantung pada material benda kerja dan material pahat. Terminologi standar pahat bubut bermata potong tunggal, sudut pahat yang paling pokok adalah sudut geram (rake angle), sudut bebas (clearance angle), dan sudut sisi potong (cutting edge angle). Sudut - sudut pahat dibentuk dengan cara diasah (pahat HSS) menggunakan mesin gerinda (tool grinder machine) seperti gambar 2 . Untuk mengenali bentuk dan geometri pahat harus dilakukan pengamatan secara sistematik. Pertama perlu dibedakan tiga hal pokok yaitu elemen, bidang aktif, dan mata potong pahat, sehingga secara lebih rinci bagian-bagiannya dapat didefinisikan. Dengan mengetahui definisinya maka berbagai jenis pahat akan mudah dikenali berdasarkan penggunaan pahat (Rochim, 2013; Dailami et.al, 20201). Pahat bubut terdapat beberapa jenis berdasarkan material pembuatannya. Jenis pahat bubut yang umum banyak digunakan adalah pahat jenis karbida dan HSS. Pahat jenis karbida umumnya banyak digunakan untuk proses pembubutan material keras, hal ini disebabkan karena pahat HSS lebih mudah aus ketika melakukan pengerjaan benda keras. Disamping itu, pahat karbida tidak bisa dibentuk karena geometri sudut pahat sudah disesuaikan dengan tool holder (pemegangnya). HSS lebih mudah dibentuk sudut-sudut geometri pahatnya dengan menggunakan mesin gerinda. Sudut potong pahat biasanya disesuaikan dengan jenis material benda kerja dan parameter permesinannya (Davis, 1995).

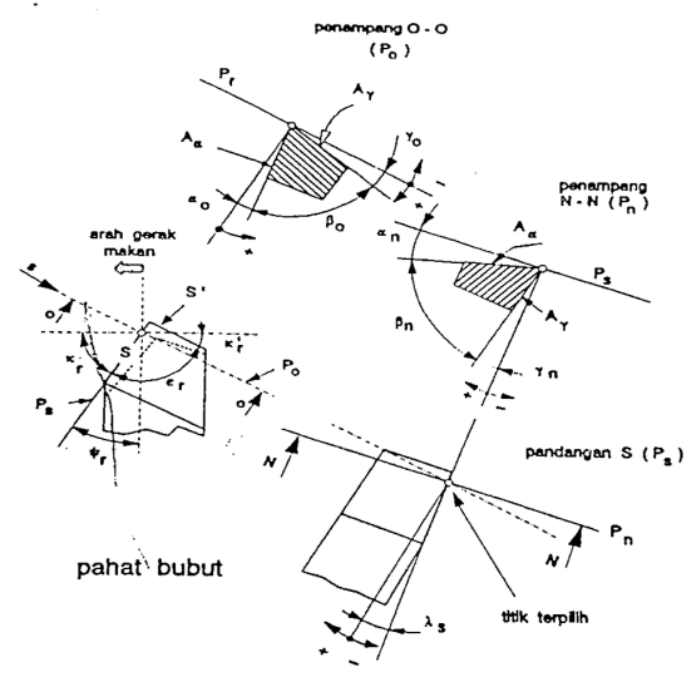

Gambar 2. Geometripahat (Rochim. 2013)

Elemen dasar dari proses pembubutan dapat dihitung menggunakan rumus dengan melihat gambar 1. Rumus-rumus untuk menghitung elemen dasar dari pembubutan yaitu.

- Kecepatanpotong

$$
v=\frac{\pi \cdot d \cdot n}{1000} ; \mathrm{m} / \mathrm{min}
$$

- Kecepatan makan

$$
v_{f}=f . n ; \mathrm{mm} / \mathrm{min}
$$

- Waktu pemotongan

$$
t_{c}=l_{t} / v_{f} ; \min
$$

Benda kerja (workpiece) :

$\mathrm{D}_{0} \quad=$ diameter mula $; \mathrm{mm}$

$\mathrm{D}_{\mathrm{m}} \quad=$ diameter akhir $; \mathrm{mm}$

$l_{t} \quad=$ panjang pemesinan $; \mathrm{mm}$

Mesin Bubut :

$\mathrm{a} \quad=$ kedalaman potong $; \mathrm{mm}$

$$
a=\left(d_{0}-d_{m} / 2\right) ; \mathrm{mm}
$$

$f \quad=$ gerak makan $; \mathrm{mm} /(\mathrm{r})$

$n=$ putaran poros utama $;(\mathrm{r}) / \mathrm{min}$

\section{B. Gaya potong}

Besarnya gaya potong merupakan informasi yang penting dan diperlukan dalam mesin perkakas, karena hal ini merupakan titik tolak dalam perhitungan dan analisis perencanaan bagi setiap jenis mesin perkakas. Demikian halnya dalam perencanaan faktor kendala (constraint) 
yang perlu diperhitungkan. Gaya pemotongan yang bereaksi pada pahat dan benda kerja yang selanjutnya diteruskan pada bagian-bagian tertentu dari mesin perkakas, akan mengakibatkan lenturan (Rochim, 2013). Alat yang digunakan untuk mengukur besarnya gaya potong yang terjadi dinamakan dynamometer. Dynamometer dipasangkan pada pahat potong, sehingga ketika proses pembubutan berlangsung, pahat yang memotong benda kerja akan menimbulkan regangan dari sensor pada dynamometer. Regangan dari sensor pada dynamometer akan dibaca oleh komputer melalui sistem akuisisi data (Sam et al., 2014).

Gaya potong yang dihasilkan dapat diketahui dengan menggunakan alat ukur (intrusment) atau load cell. Nilai yang dihasilkan load cell dalam satuan gram maka akan dikonversikan ke Newton, seperti persamaan dibawah ini.

$$
\begin{aligned}
& F=\frac{\text { beban }}{1000} \times g\left(m / s^{2}\right) \\
& F: \text { Gaya }(\mathrm{N}) \\
& g: \text { Gravitasi }\left(9.801 \mathrm{~m} / \mathrm{s}^{2}\right)
\end{aligned}
$$

\section{METODE}

\section{A. Instrumen Penelitian}

Peralatan yang digunakan untuk memperoleh data yang sesuai dengan tujuan penelitian adalah :

1. Mesin bubut konvensional Emco V - 13 ip 54

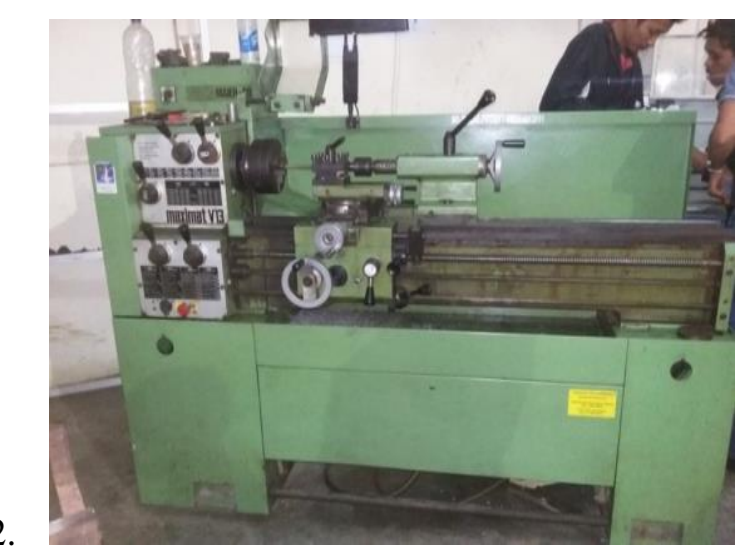

Gambar 3. Mesin Bubut Emco V-13 IP 54
3. Instrumen pendukung yang dirangkai untuk mendapatkan hasil data dari pengujian terdiri dari .

4. lood cell, thermocouple, photoelectrik counter, arduino, layar lcd dan laptop.Keakuratan dalam pengambilan data sensor lood cell yang dipakai untuk mengukur gaya yang terjadi pada saat proses pemesinan telah dikalibarasi, keakuratan memang masih belum mencapai nilai maksimum dari alat kalibrasinya. Tingkat keakuratan masih mencapai 55\%. Pada gambar 4 terlihat alat instrumentasi yang dipasang untuk pengambilan data pengujian.

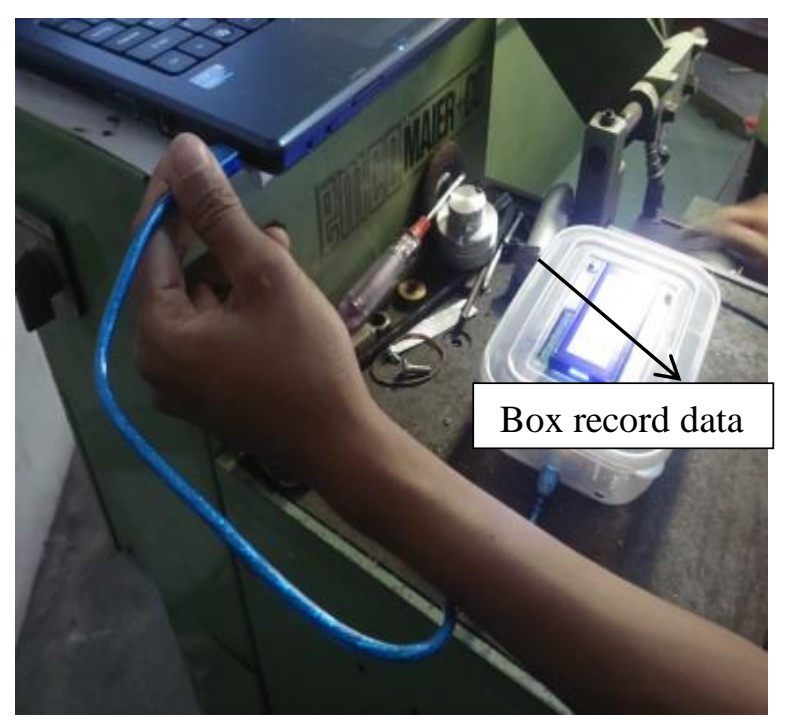

Gambar 4. Instrumen Alat ukur

\section{B. Bahan Penelitian}

Dua jenis logam alumunium yang dipakai pada penelitian yaitu alumunium dural $\mathrm{Al} 2024$ (a) dan alumunium murni Al 1100 (b) dipakai untuk spesimen benda kerja pada penelitian ini.

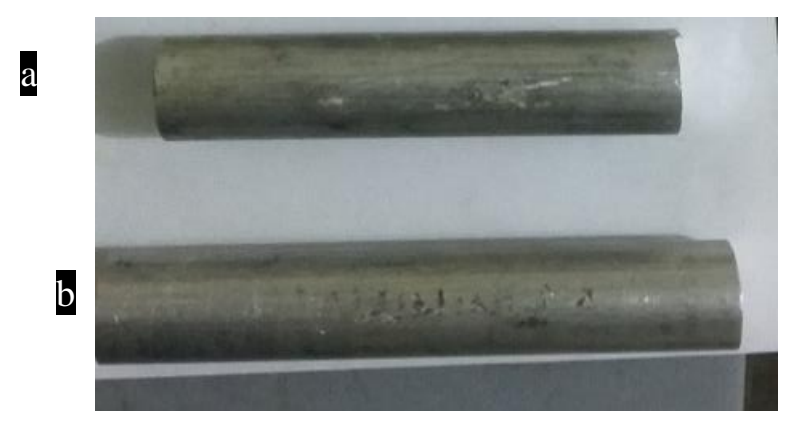

Gambar 5. Spesimen Benda Kerja 
Pahat yang digunakan adalah jenis pahat insertcarbide yaitu pahat insert DCGT 070204K10 dan DCMT 070202-M20. Dapat dilihat pada gambar 6.

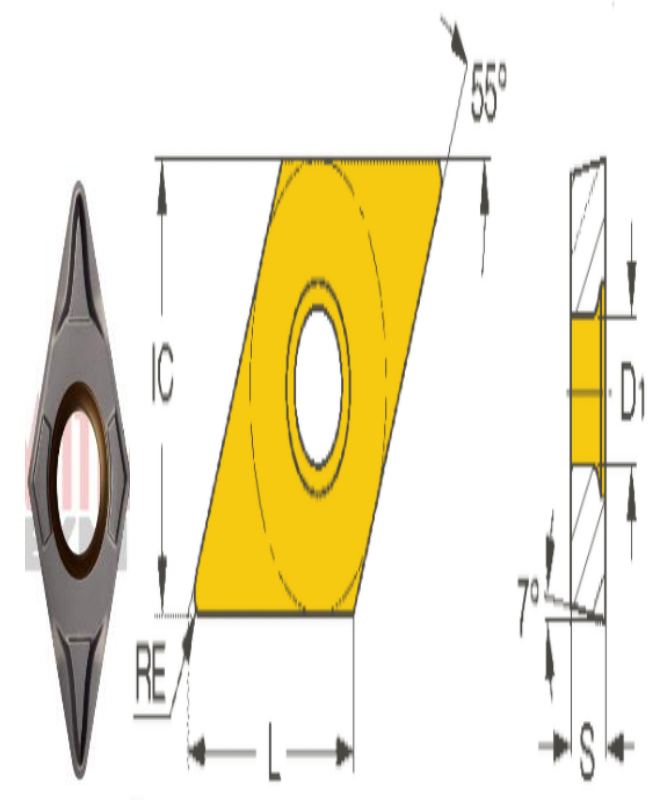

Gambar 6. Dimensi mata pahat insert

Pada penelitian ini parameter kecepatan putaran spindle diberikan pada tabel 1.

Tabel 1. Parameter kecepatan spindle dan jenis pahat

\begin{tabular}{|cccc|}
\hline $\begin{array}{c}\text { Jenis } \\
\text { Pahat }\end{array}$ & $\begin{array}{c}\text { Putaran } \\
\text { Spindle } \\
\text { (rpm) }\end{array}$ & Spesimen & $\begin{array}{c}\text { Kedalaman } \\
\text { Potong } \\
(\mathrm{mm})\end{array}$ \\
DCGT & & & \\
070204- & 90 & Al 1100 & \\
K10 & 110 & dan & 0.3 \\
DCMT & 155 & Al 2024 & \\
070202- & 190 & & \\
M20 & & & \\
\hline
\end{tabular}

\section{Metode Pengambilan Data Pengujian}

1. Memasang instrumen tasi pada penjepit pahat (tool post) mesin bubut dan terlebih dahulu melakukan penyetalan center mata pahat pada kepala lepas (tail stock). Pada kepala lepas telah dipasang sensor load cell untuk melihat besarnya gaya potong yang terjadi pada saat pengujian. Lood cell yang digunakan keakuratannya telah dikalibrasi sebelumnya, tingkat keakuratan mencapai $55 \%$.

2. Memasang plat sensor pada sebanyak 3 buah pada kepala chuck dengan 3 titik sudut yang berbeda.

3. Memasang sensor photo electric counter module.

4. Menghubungkan sensor photo electric counter module kerangkaian pada program Arduino.

5. Menghubungkan rangkaian Arduino pada laptop.

6. Memasang spesimen pada chuck mesin bubut.

7. Mengatur spindle kecepatan putaran pembubutan sesuai data yang diiginkan yaitu putaran 90,110,155,190 rpm.

8. Menghidupkan mesin serta mensetting nol pahat ke benda kerja dan selanjutnya melakukan pemakan kedalam benda kerja sebesar $0,3 \mathrm{~mm}$.

9. Menyambungkan dan merekam data pada saat pengujian.

10. Menyimpan data hasil penelitian yang yang muncul pada layar laptop dengan software Plx Daq dan di record oleh Arduino Uno.

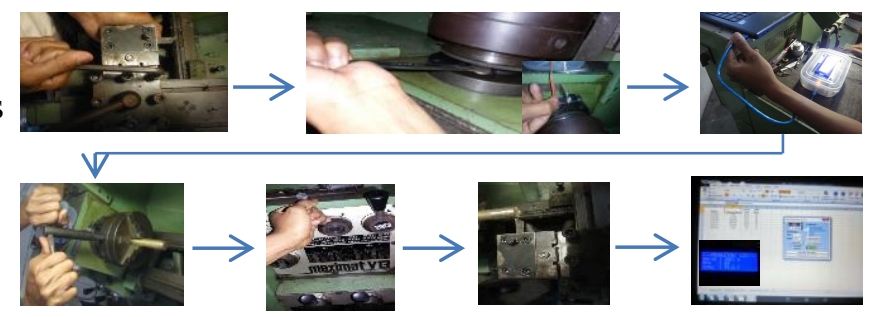

Gambar 7. Skema Pengambilan Data

\section{HASIL DAN PEMBAHASAN}

\section{A. Hasil Pengujian}

Dari hasil pengujian yang sudah dilakukan didapatkan berupa nilai gaya potong dengan putaran yang berbeda. Hasil pengukuran gaya potong dalam satuan gram dan di konversikan dengan rumus (5). Hasil pengujian pada material (Al 1100) ditunjukkan pada tabel 2. 
Tabel 2. Hasil pengujian pada spesimen Al 1100

\begin{tabular}{cccccc}
\hline \multicolumn{3}{c}{ DCMT M20 } & \multicolumn{3}{c}{ DCGT K10 } \\
\hline $\begin{array}{c}\text { Putaran } \\
\text { (rpm) }\end{array}$ & Beban (gr) & $\begin{array}{c}\text { Gaya } \\
(\mathrm{N})\end{array}$ & $\begin{array}{c}\text { Putaran } \\
(\mathrm{rpm})\end{array}$ & Beban (gr) & $\begin{array}{c}\text { Gaya } \\
(\mathrm{N})\end{array}$ \\
90 & 1010.19 & 9.91 & 90 & 430,67 & 4.22 \\
110 & 816.5 & 8.01 & 110 & 425,73 & 4.18 \\
155 & 758.11 & 7.44 & 155 & 315,04 & 3.09 \\
190 & 695.72 & 6.83 & 190 & 295,71 & 2.90 \\
\hline
\end{tabular}

Dari hasil yang ditunjukan pada tabel 2, dapat diketahui pada pahat DCMT M20 lebih besar gaya potong yang terjadi dibandingkan dengan pahat DCGT K10. Perbandingan dari kedua pahat dapat dilihat pada gambar 8.

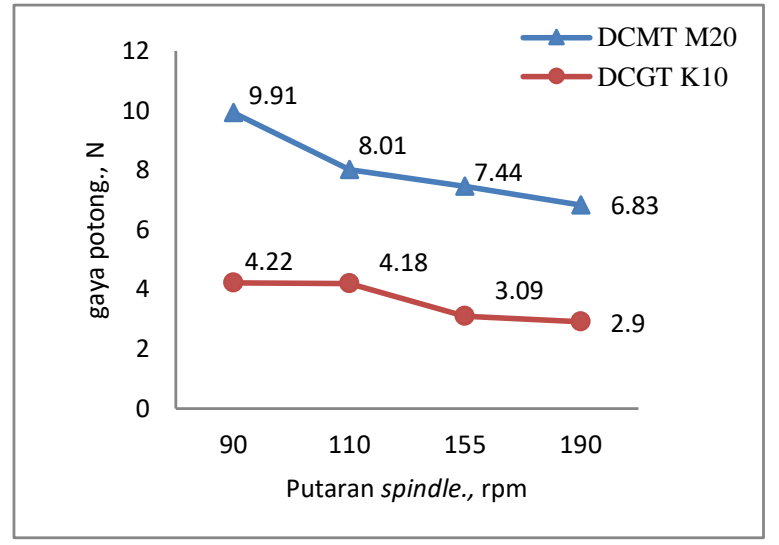

Gambar 8. Grafik hubungan gaya potong dengan putaran spindle ( $\mathrm{Al} 1100)$

Hasil pengujian pada Al 1100 menunjukkan bahwa semakin tinggi putaran spindle maka nilai gaya potong akan menurun. Nilai gaya potong pada mata pahat insert DCMT M20 putaran 90 rpm sebesar $9.91 \mathrm{~N}$, sedangkan pada putaran 190 $\mathrm{rpm}$ nilai gaya potong menurun menjadi $6.83 \mathrm{~N}$. Selanjutnya menggunakan pahat insert DCGT K10 di putaran $90 \mathrm{rpm}$ gaya yang terjadi sebesar 4.22 $\mathrm{N}$, sedangkan pada putaran $190 \mathrm{rpm}$ gaya yang terjadi menurun menjadi $2.90 \mathrm{~N}$.

Selanjutnya hasil pengujian pada material $\mathrm{Al}$ 2024 dapat dilihat pada table 3. Sama hal-nya seperti pengujian sebelumnya pada material $\mathrm{Al}$ 1100 , nilai gaya yang terjadi pada putaran rpm rendah lebih besar dibandingkan rpm tinggi. Pada rpm 90 rpm menggunakan jenis pahat DCMT gaya yang terjadi $8.34 \mathrm{~N}$ dan pada putaran $190 \mathrm{rpm}$ gaya yang terjadi $4.56 \mathrm{~N}$. Kemudian gaya yang terjadi pada material Al 2024 menggunakan jenis pahat DCGT pada putaran $90 \mathrm{rpm}$ sebesar $3.84 \mathrm{~N}$ dan pada putaran $190 \mathrm{rpm}$ sebesar $3.2 \mathrm{~N}$.
Table 3. Hasil pengujian pada spesimen Al 2024

\begin{tabular}{cccccc}
\hline \multicolumn{3}{c}{ DCMT } & \multicolumn{3}{c}{ DCGT } \\
\hline $\begin{array}{c}\text { Putaran } \\
(\mathrm{rpm})\end{array}$ & $\begin{array}{c}\text { Beban } \\
(\mathrm{gr})\end{array}$ & $\begin{array}{c}\text { Gaya } \\
(\mathrm{N})\end{array}$ & $\begin{array}{c}\text { Putaran } \\
(\mathrm{rpm})\end{array}$ & $\begin{array}{c}\text { Beban } \\
(\mathrm{gr})\end{array}$ & $\begin{array}{c}\text { Gaya } \\
(\mathrm{N})\end{array}$ \\
90 & 850.52 & 8.34 & 90 & 391 & 3.84 \\
110 & 836.2 & 8.2 & 110 & 374.08 & 3.67 \\
155 & 746.6 & 7.32 & 155 & 353 & 3.46 \\
190 & 465.26 & 4.56 & 190 & 326.19 & 3.2 \\
\hline
\end{tabular}

Perbandingan dari dua jenis pahat yang digunakan dapat ditunjukkan pada gambar 9. Dari hasil yang ditunjukan pada tabel 3, dapat diketahui pada pahat DCMT M20 lebih besar gaya potong yang terjadi dibandingkan dengan pahat DCGT K10.

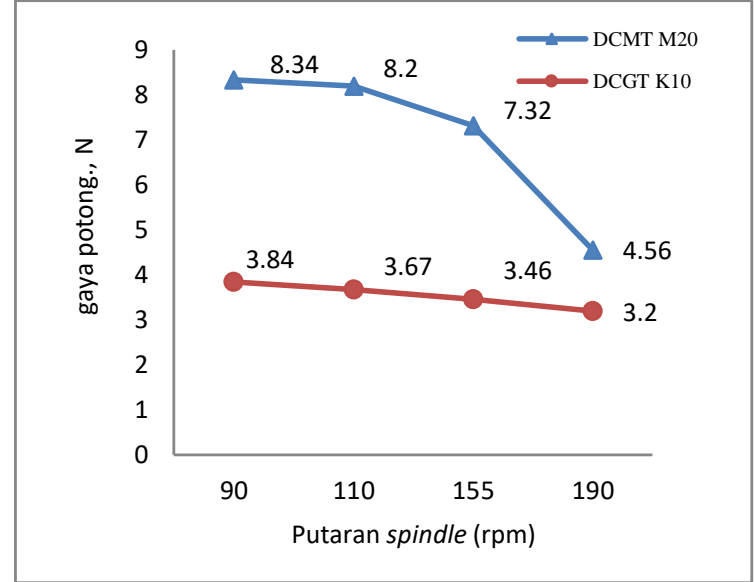

Gambar 9. Grafik hubungan gaya potong dengan putaran spindle (Al 2024)

Perbandingan nilai gaya potong yang terjadi dengan menggunakan pahat yang sama ditunjukkan pada gambar 10. Hasil dari pengujian nilai gaya potong yang tertinggi antara kedua material yaitu pada material Al 1100 menggunakan pahat insert DCMT. Nilai gaya potong pada material Al 1100 di kecepatan putaran $90 \mathrm{rpm}$ sebesar $9.91 \mathrm{~N}$ dan pada material Al 2024 di kecepatan rpm yang sama sebesar $8,34 \mathrm{~N}$. Ini menunjukkan bahwa perubahan gaya potong dipengaruhi oleh sifat mekanik dari kedua material. Sifat mekanik kedua material sudah pasti berbeda. Kekuatan mekanik sangat mempengaruhi gaya potong yang terjadi pada pemesinan ( $\underline{\text { schmid }}$ $\underline{\text { \& Technology, n.d.). }}$ 


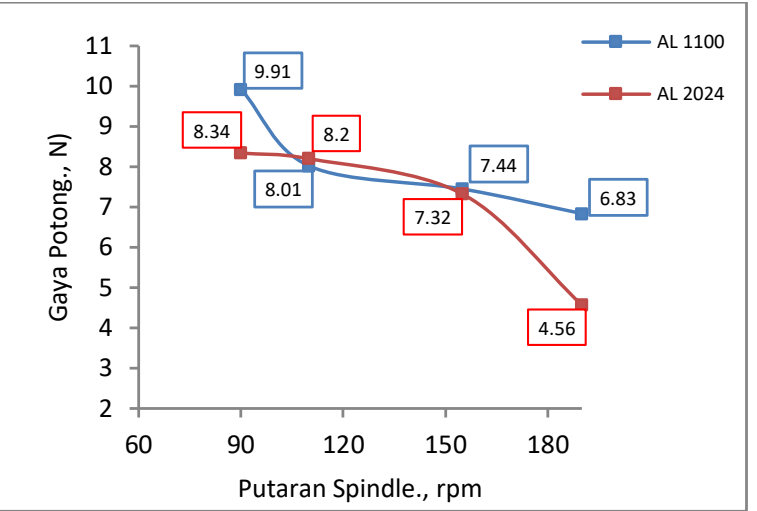

Gambar 10. Grafik hubungan gaya potong dengan putaran spindle menggunakan pahat insert DCMT

Hasil yang sama ditunjukkan pada gambar 11, penurunan nilai gaya potong menggunakan pahat insert DCGT menurun seiring dengan naiknya putaran spindle yang digunakan. Nilai gaya potong yang tertinggi pada material $\mathrm{Al} 1100$ di putaran 90 rpm gaya potong sebesar $4.22 \mathrm{~N}$, sedangkan pada Al 2024 gaya potong pada putaran yang sama sebesar $3.84 \mathrm{~N}$.

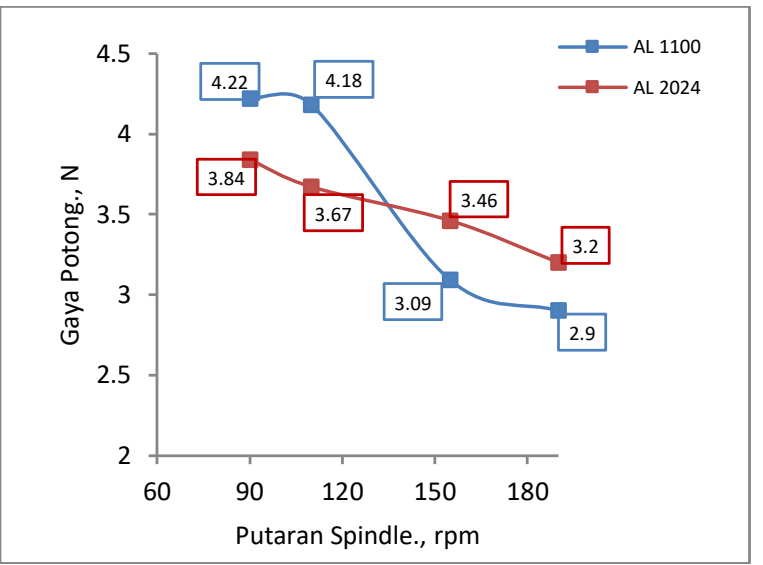

Gambar 11. Grafik hubungan gaya potong dengan putaran spindle menggunakan pahat insert DCGT

\section{B. Pembahasan}

Dari hasil pengamatan, terjadi perbedaan nilai gaya potong yang terjadi pada proses pemesinan antara dua jenis pahat. Dari jenis pahat tersebut, nilai gaya yang terkecil pada proes pemesinan menggunakan dua jenis material yang berbeda yaitu Al 1100 dan Al 2024 adalah jenis pahat DCGT K-10 (Siddesh Kumar et al., 2017). Kemudian besarnya nilai gaya potong yang terjadi pada proses pemesinan tergantung dengan seberapa besar putaran spindle yang dipakai, semakin besar putaran yang dipakai maka semakin kecil nilai gaya yang terjadi, getaran yang timbul ketika putaran tinggi sangat kecil dibandingkan dengan putaran rendah yang menimbulkan getaran yang besar (Pattnaik, 2020) (Nasution, 2020). Gaya potong pada pemesinan dapat meningkat dipengaruhi oleh sifat mekanik dari material uji tersebut (Kalpakjian, 2009).

\section{KESIMPULAN}

\section{A. Kesimpulan}

Getaran yang timbul pada proses pemesinan ini adalah faktor utama terjadinya gaya potong. Penurunan gaya potong ketika menggunakan rpm tinggi yaitu $190 \mathrm{rpm}$. Ketika rpm tinggi digunakan maka getaran yang muncul semakin kecil.

Dari dua jenis material yang dipakai pada penelitian ini gaya potong yang dihasilkan berbeda. Karena sifat dari masing-masing material tersebut berbeda.

\section{B. Saran}

Kedepannya penulis berharap bisa melanjutkan penelitian ini dengan menambahkan sebuah perangkat pembantu (sensor) untuk melihat temperatur bahan pada saat proses pemesinan dilakukan untuk melihat pengaruh suhu terhadap gaya potong. Serta peneliti selanjutnya dapat melakukan uji sifat mekanik dari material.

\section{REFERENSI}

Bharilya, R. K., Malgaya, R., Patidar, L., Gurjar, R. K., \& Jha, A. K. (2015). Study of Optimised Process Parameters in Turning Operation Through Force Dynamometer on CNC Machine. Materials Today: Proceedings. https://doi.org/10.1016/j.matpr.2015.07.268

Cetin, M. H., Ozcelik, B., Kuram, E., \& Demirbas, E. (2011). Evaluation of Vegetable Based Cutting Fluids with Extreme Pressure and Cutting Parameters in Turning of AISI 304L by Taguchi Method. Journal of Cleaner Production, 19(17-18), 2049-2056. https://doi.org/10.1016/j.jclepro.2011.07.013

Davis, J. R. (1995). General Guidelines for Selecting Cutting Tool Materials. www.asminternational.org

Dailami, D., Pribadyo, P., \& Hanif, H. (2020). Pengaruh Komposisi Dan Kuat Tekan terhadap Tingkat Kerapuhan Briket Arang Biomasa Campur Batubara dengan Tepung 
Kanji sebagai Perekat. VOCATECH: Vocational Education and Technology Journal, 2(1), 67-72.

Günay, M., Korkut, İ., Aslan, E., \& Şeker, U. (2008). Experimental Investigation of The Effect of Cutting Tool Rake Angle on Main Cutting Force. Journal of Materials Processing Technology, 166(1), 44-49. https://doi.org/10.1016/j.jmatprotec.2004.07. 092

Husni, T., Pusvyta, Y., \& Hidayat, T. (2019). TEKNIKA: Jurnal Ilmiah Pengaruh Jenis Pahat dan Kedalaman Pemakanan pada Proses Pembubutan terhadap Kekasaran Permukaan AISI 4340 Fakultas Teknik Universitas IBA TEKNIKA: Jurnal Ilmiah Fakultas Teknik Universitas IBA. TEKNIKA, 6(2), 119-133.

Iqbal, M., Ariff, T. F., bin Mat Roseh, M. S. F., Al-Hazza, M. H. F., Hilmy, I., \& Suryanto. (2015). Effect of Microwave Sintering Treatment to The Flank Wear of Titanium Carbide Tools in Milling Operations. Advanced Materials Research, 1115(June 2016), 59-63. https://doi.org/10.4028/www.scientific.net/a mr.1115.59

Jiang, Z., Zhou, F., Zhang, H., Wang, Y., \& Sutherland, J. W. (2015). Optimization of Machining Parameters Considering Minimum Cutting Fluid Consumption. Journal of Cleaner Production, 108, 183191.

https://doi.org/10.1016/j.jclepro.2015.06.007

Kalpakjian, S. (2009). Manufacturing Engineering \& Technology. In Prentice Hall.

Kosaraju, S., Anne, V., \& Ghanta, V. (2011). Effect of Rake Angle and Feed Rate on Cutting Forces in An Orthogonal Turning Process. International Conference on Trends in Mechanical and Industrial Engineering, May, 150-154.

M. Rizal, J.A. Ghani, Husni, H. (2018). Design and Construction of A Strain Gauge-Based Dynamometer for A 3-Axis Cutting Force Measurement in Turning Process. Journal of Mechanical Engineering and Sciences, 12(4), 4072-4087.

https://doi.org/https://doi.org/10.15282/jmes. 12.4.2018.07.0353 Design

Muhklisin, M., Ramadhan, M. E., \& Mulyadi, S. (2020). Analisa Gaya Radial pada Proses Turning Menggunakan Sensor Strain Gauge Radial Force Analysis in The Turning
Process Using Strain Gauge Sensor. JMEMME, $\quad 4(2), \quad$ 144-151. https://doi.org/10.31289/jmemme.v4i2.3992

Nasution, A. R. (2019). Jurnal Rekayasa Material , Manufaktur dan Energi FT-UMSU Jurnal Rekayasa Material, Manufaktur dan Energi FT-UMSU. Jurnal Rekayasa Material, Manufaktur dan Energi Http://Jurnal.Umsu.Ac.Id/Index.Php/RMME, $3(1), 16-22$.

Nasution, A. R., Fuadi, Z., Hasanuddin, I., \& Kurniawan, R. (2020). Effect of Vegetable Oils As Cutting Fluid on Wear of Carbide Cutting Tool Insert in A Milling Process. IOP Conference Series: Materials Science and Engineering, 796(1), 0-10. https://doi.org/10.1088/1757899X/796/1/012001

Pattnaik, S. K., Behera, M., Padhi, S., Dash, P., \& Sarangi, S. K. (2020). Study of Cutting Force and Tool Wear During Turning of Aluminium with WC, PCD and HFCVD Coated MCD tools. Manufacturing Review, 7. https://doi.org/10.1051/mfreview/2020026

Rizal, M., Ghani, J. A., Nuawi, M. Z., \& Che Haron, C. H. (2015). Development and Testing of An Integrated Rotating Dynamometer on Tool Holder for Milling Process. Mechanical Systems and Signal Processing, 52-53, 559-576. https://doi.org/https://doi.org/10.1016/j.ymss p.2014.07.017

Rochim, T. (2013a). Proses Permesinan Buku 4: Perkakas \& Sistem Pemerkakasan Umur Pahat, Cairan Pendingin Pemesinan. In Journal of Chemical Information and Modeling.

Sam, G., Djoko, D., \& Arifin, Z. (2014). Rancang Bangun Dynamometer untuk Pengukuran Gaya Potong Mesin Bubut. Mekanika, 12, 94-100.

Scheffer, C., \& Heyns, P. S. (2004). An industrial Tool Wear Monitoring System for Interrupted Turning. Mechanical Systems and Signal Processing, 18(5), 1219-1242. https://doi.org/https://doi.org/10.1016/j.ymss p.2003.09.001

Schmid, K. •, \& Technology, M. E. and. (n.d.). Chapter 1: The Structure of Behavior. In Explaining Behavior. https://doi.org/10.7551/mitpress/2927.003.00 02

Siddesh Kumar, N. G., Shiva Shankar, G. S., Ganesh, M. N., \& Vibudha, L. K. (2017). 
Experimental Investigations to Study the Cutting Force and Surface Roughness during Turning of Aluminium Metal Matrix Hybrid Composites. Materials Today: Proceedings, 4(9), 9371-9374. https://doi.org/https://doi.org/10.1016/j.matpr .2017.06.187

Susila, I. N., Arifin, Z., \& Susilo, D. D. (2013).

Pemotongan pada Proses Bubut Beberapa

Material dengan Pahat HSS Mekanika,

12(September), 28-33. 